DRUŠ. ISTRAŽ. ZAGREB

GOD. 20 (2011),

RECENZIJE I PRIKAZI

BR. 3 ( 113$)$

STR. 899-911

higijensko-zdravstvenim uvjetima, ali se stanje postupno popravljalo. Đački se internat u Karlovcu i Zagrebu navezao na djelovanje Pazinske gimnazije, nastavljajući u tom smislu i nedovršeni predratni proces nacionalne integracije istarskih $\mathrm{Hr}$ vata.

A istarski Hrvati koji u međuraću nisu emigrirali bili su izloženi raznoraznim pritiscima talijanskih vlasti. Prilog poznavanju rezultata takve denacionalizatorske politike pruža članak "O propasti talijanske politike odnarođivanja u Istri (tajno popisivanje istarskih Hrvata 1939.)" (103-123). Iako literatura spominje "popis inojezičnog pučanstva u sjeveroistočnim provincijama Italije iz 1939.", spis koji je danas dostupan isključivo kao mikrofilmska kopija koja se čuva u National Archives $\mathrm{u}$ Washingtonu, zapravo je nastao analizom obiteljskih popisnih listova iz 1936. godine. Njihovom obradbom rimski je Središnji zavod za statistiku došao do podataka o tzv. inojezičnome pučanstvu, a Maninova raščlamba pokazuje potpun neuspjeh dvadesetogodišnje nasilne talijanizacije, o čemu svjedoče i detaljne, radu priložene, tablice.

Završno poglavlje "O ljudskim gubicima i egzodusu iz Istre $u$ drugome svjetskom ratu i poraću" (125-140) posvećeno je temi koja i danas uzbuđuje duhove, posebno ako se iskorištava u dnevnopolitičke svrhe. Uz iscrpan osvrt na dosadašnju literaturu, u članku se obrađuje pitanje tzv. jama, koje su postale sinonimom za ljudske gubitke nakon kapitulacije Italije 1943. te potkraj rata u svibnju 1945. godine. Prikazano je i, s poratnim nasiljem povezano, pitanje poratnoga egzodusa. Oba su problema uklopljena u povijesni kontekst. Studije skupljene u monografiji "Istra na raskrižju: O povijesti migracija pu- čanstva Istre" ispunjavaju dvojak zadatak: oslanjajući se na širok izbor literature o istarskoj povijesti, upozoravaju na dosadašnji stupanj istraženosti pojedinih historiografskih tema, povezanih s migracijama istarskoga stanovništva. Istodobno, autorovi su uvidi nesumnjiv istraživački doprinos obrađenoj problematici te, kao takvi, ispunjavaju svrhu naznačenu u uvodu, a to je "pružanje bilance o stečenim spoznajama i poticanje novih istraživanja."

Mihovil Dabo

doi:10.5559/di.20.3.19

\section{Nada Gosić, Brigitte E. S. Jansen (ur.) HRVATSKA: POLITIKA, PRAVO, PRAVA paciJenata I eUtaNAZIJA / CROATIA: POLITICS, LEGISLATION, PATIENT'S RIGHTS AND EUTHANASIA}

Martin Meidenbauer Verlagsbuchhandlung, München, 2011., 122 str.

Nedavno održana bioetička zbivanja u Rijeci i Malom Lošinju (13. dani bioetike $u$ Rijeci, 13. - 14. svibnja, 2011. i 10. lošinjski dani bioetike, 16. - 18. svibnja, 2011.), osim ostalih znanstvenih aktivnosti, za širu su javnost ujedno bila prilika upoznavanja s recentnim bioetičkim publikacijama, među kojima za ovu priliku izdvajamo knjigu Hrvatska: Politika, pravo, prava pacijenata i eutanazija (Croatia: Politics, Legislation, Patient's Rights and Euthanasia). Riječ je o knjizi njemačke izdavačke kuće Martin Meidenbauer, urednice su Nada Gosić i Brigitte E. S. Jansen, a u njoj su tekstovi četiriju autora/ica: Nade Gosić, Amira Muzura, Ive Rinčić i Hrvoja Jurića. 
DRUŠ. ISTRAŽ. ZAGREB

GOD. 20 (2011),

BR. 3 (113)

STR. 899-911

Kao peti dio niza edicije Pravo, sistem javnog zdravstva i društvo (Law, Public Care System and Society), ova je knjiga ujedno treća u nizu uspješne suradnje Nade Gosić i Brigitte Jansen, u kojima prvi put dijele ulogu suurednica.

Prvi dio knjige objedinjuje dva manja teksta: Editorial, u kojem Jansen u kratkim crtama ističe karakter edicije kojoj knjiga pripada te navodi činjenicu njezina sve većega značenja $u$ javnosti. Razloga je za to više. Baveći se raznolikim društvenim konotacijama, etičkim dvojbama, ekonomskim računicama i pravnim normama na području zdravstva, edicija Pravo, sistem javnog zdravstva $i$ društvo teži sustavnim prikazima i razradbi problema, posebno promičući specifične potrebe građana u sklopu zdravstvenih sustava pojedinih zemalja U ovoj je knjizi u središtu interesa hrvatski zdravstveni sustav, što je činjenica važna iz najmanje dvaju razloga: suradnjom sa stranom izdavačkom kućom nedvojbeno se promoviraju hrvatski autori i izvan (uskih) nacionalnih okvira, no još važnije - obrađena se problematika sagledava u posve drugačijem međunarodnom kontekstu. Naime, nedovoljno artikulirana, no zasigurno prisutna činjenica hrvatskoga zdravstva jest općeprisutna tendencija opravdavanja trenutačnoga stanja posljedicama tranzicije i kroničnoga manjka sredstava. Naviknutost na takvo stanje zadanosti (i zarobljenosti) tranzicijom u Hrvatskoj postupno poprima goleme razmjere, no valja očekivati da će se prave posljedice zatvorenosti za nove ideje, otvoreni dijalog i traženje konstruktivnih rješenja još dugo osjećati. S tim u vezi, ova je knjiga važan iskorak otvaranja problema hrvatskoga zdravstva i drugačijim perspektivama od onih na koje smo uobičajeno navikli.
Spomenutim se trendovima u svojem Uvodniku (Foreword) pozabavila Nada Gosić, smjestivši problem suvremenoga hrvatskog zdravstva u društveni kontekst, smjenu političkih sustava te šire razmjere strukturalnih promjena u zdravstvu (s naglaskom na privatizaciju i komercijalizaciju), istodobno nas uvodeći i u sam metodološki pristup knjige, naglasivši važnost sistematične analize, interdisciplinarnost $i$ profesionalnost diskusije, ali i integriranost raznih pristupa u zajedničku matricu bioetičke pluriperspektivnosti.

U prvom prilogu Politički utjecaji na rad zdravstvenih institucija u Republici Hrvatskoj - normativna i praktična perspektiva (Political influence on the work of health institutions in the Republic of Croatia - normative and practical perspective) autorica Nada Gosić bavi se utjecajima i razmjerima političkih intervencija $u$ radu medicinskih i zdravstvenih institucija (bolnice, klinički bolnički centri, ljekarne ...), i to analizom sadržaja temeljenih normativnih akata statuta spomenutih institucija. Provedenom metodom autorica je upozorila na probleme, poput uniformirane standardizacije (bez obzira na to o kojoj je instituciji riječ), visoke indikacije političkih utjecaja (poput političkog izbora predstavnika izvršnih tijela) te zatvorenosti prema drugim perspektivama. U nastavku, osvrnuvši se i na praktičnu perspektivu političkog utjecaja u zdravstvu, Gosić je podsjetila na rezultate okrugloga stola Aktualni trenutak hrvatskog zdravstva (Rijeka, 11. siječnja, 2011.), posebno na važnost primjene Riječkog apela racionalnog i etičkog zdravstva u samu zdravstvenu praksu.

Aktualni trenutak hrvatskog zdravstvenog sustava (The current moment of Croatian healthcare system) naziv je priloga Amira Muzura, $\mathrm{u}$ kojem autor nudi povijesni pregled / presjek razvoja javnoga zdravstva u Hrvatskoj. Iako je naglasak na suvremenom trenutku, iz pozicije povjesničara medicine Muzur u svojem radu ne izostavlja prethodne etape, posebno se osvrnuvši na ključni trenutak: djelovanje Andrije Štampara 1920-ih, koji je, nažalost, često zane- 
DRUŠ. ISTRAŽ. ZAGREB GOD. 20 (2011), BR. 3 (1 13), STR. 899-911

maren u naše vrijeme. Vještim konfrontiranjem svijetle i tamne strane autor jasno iščitava glavne boljke suvremenoga hrvatskog zdravstva. To su: već spomenuta pretjerana politizacija, nedostatna medicinska edukacija, pravno ukalupljenje medicine i, naravno, korupcija. Poput prethodne autorice, Muzur svijetlu točku također vidi u 10 teza objedinjenih u Riječkom apelu, odnosno u njihovu beskompromisnom prevođenju iz pukoga slova na papiru u stvarni život hrvatskoga zdravstva. Iva Rinčić autorica je rada Prava pacijenata u Hrvatskoj: pravni okvir i stvarna ostvarenja (Patient's rights in Croatia: legal framework and actual accomplishments). Ovo osjetljivo pitanje, s obzirom na to da je riječ o posebno ranjivoj skupini društva s čijim se pravima nerijetko manipulira i gotovo trguje, autorica je nastojala smjestiti u povijesnu dimenziju obilježenu snažnim paternalizmom. U kontekstu suvremenih bioetičkih rasprava, prava pacijenata odnedavno su postala jedna od gorućih društvenih tema te ujedno pitanje pravne regulacije (što je slučaj i u Hrvatskoj - Zakon o zaštiti prava pacijenata, NN 169/2004.). Ipak, realnost sustava zdravstva u Hrvatskoj često pokazuje gotovo nepremostiv jaz između propisanih normi i njihove primjene i, što je još ozbiljnije, nisku razinu upućenosti zainteresiranih skupina / pacijenata u vlastita prava. Trenutačna situacija nije optimistična i zahtijeva ozbiljne promjene u shvaćanju društvenih prioriteta, no već i sad ima primjera koji se nude kao mogućnost rješenja - poput udruga civilnoga društva, zaključuje Rinčić.

Posljednji rad nosi naslov Eutanazija u kontekstu hrvatskog zdravstvenog sustava, prava i bioeticke rasprave (Euthanasia in the context of Croatian healthcare system, legislation and bioethical discussion) autora Hrvo- ja Jurića, ujedno jedinog autor koji ne dolazi s Katedre za društvene i humanističke znanosti u medicini (Medicinski fakultet Sveučilišta u Rijeci), nego sa zagrebačkoga Filozofskog fakulteta (Odsjek za filozofiju - Katedra za etiku). Pronašavši polazište razradbe problema eutanazije $\mathrm{u}$ etičkom kodeksu (Kodeks medicinske etike i deontologije) i hrvatskom Kaznenom zakonu, Jurić u drugom dijelu teksta ne izostavlja u svoju raspravu uključiti i druge bioetičke perspektive (filozofsku, teološku, sociološku ...), pri čemu je njegov naglasak na bitnim momentima rasprave o eutanaziji u Hrvatskoj u zadnjih 5-10 godina. Iako autor ističe da njegov rad ne može ponuditi sustavan prikaz problema, nema sumnje da je riječ o kvalitetnom interdisciplinarnom sukusu ove zahtjevne teme, kojoj ne nedostaje inteligentnih zapažanja, smjelih konstatacija i konstruktivnih rješenja.

Zaključimo. Knjiga Hrvatska: Politika, pravo, prava pacijenata $i$ eutanazija zacijelo nije odgovorila na sve probleme i izazove hrvatskoga zdravstva, no nedvojbeno je ponudila smion metodološki iskorak. $\mathrm{S}$ tim u vezi, razmišljanja na tragu iznesenih ideja i perspektiva trebala bi imati dvostruku ulogu: biti preporuka čitanju knjige, a u isti mah i poticaj nekim novim izdavačkim projektima na započetim osnovama.

Iva Rinčić 